\section{Evaluation of chronic toxicity of Kushta Sammulfar (calx of Arsenic trioxide)}

\author{
Athar Parvez Ansari, ${ }^{1}$ Abdul Wadud, ${ }^{1}$ \\ Najeeb Jahan, ${ }^{1}$ \\ Renuka Bangalore Nagaraj, ${ }^{1}$ \\ Shamim Irshad, 2 \\ Syed Mohd. Faisal Iqbal ${ }^{3}$ \\ ${ }^{1}$ National Institute of Unani Medicine, \\ Kottigepalya, Bangalore; ${ }^{2}$ Jamia Tibbia \\ Deoband, Deoband, Uttar Pradesh; \\ 3S.H.U. Tibiya College, Ganpati Naka, \\ Burhanpur, Madhya Pradesh, India
}

\section{Abstract}

Sammulfar (arsenic trioxide) is a notorious poison and has extensively been studied for its toxicity. It is in use for various purposes for centuries and is used even today as a therapeutic agent in the form of kushta (calx) in traditional systems of medicine, particularly Unani medicine, but without apparent safety data. The present study, therefore, was conducted to produce data for prolong use of calx of arsenic trioxide. The calx (test drug) was prepared by the method described in National Formulary of Unani Medicine. The study was carried in healthy Wistar rats of either sex; weighing 150-250 g; 23 months of age, in a dose dependent manner, following the methods of Gupta et al. (2002), Ghosh (2008) and Klaassan (2008). The animals were divided into four groups of 10 animals each. Group I served as control, where as group II, III and IV were used for three dose levels of the test drug i.e. low $\left(8.75 \mathrm{mg}^{-1} \mathrm{~kg}\right)$, medium $\left(17.50 \mathrm{mg}^{-1} \mathrm{~kg}\right)$ and higher $\left(26.25 \mathrm{mg}^{-1} \mathrm{~kg}\right)$. Standard parameters usually applied for chronic toxicity studies were considered. The study revealed dose dependent toxicity. Usual signs of chronic toxicity were observed during the study. Low dose of Kushta Sammulfar (KSF) did not produce remarkable toxic effects. Mild to moderate toxicity was seen in KSF-II and KSF-III.

\section{Introduction}

Though the traditional systems of medicine prefer plant origin drugs, but some metals and minerals are also used as drugs in certain cases, that may produce moderate to severe toxicity even at therapeutic dose level if used unjudiously. Therefore, because of likelihood of toxicity and pharmacokinetic inconvenience such drugs are detoxified by various means. Taklees (calcination) practiced in Unani medicine is one of the detoxification methods in which metals and minerals are incinerated at high temperature ${ }^{1}$ so as to reduce the elements of toxicity. In Unani medicine, the incinerated substance, which changes into oxide form, is known as Kushta, a Persian word, meaning killed $^{2}$ and refers to a substance that has been killed (incinerated) at high temperature (usually $>500^{\circ} \mathrm{C}$ ). In this method, fire of cow dung cakes is used as the source of heat. Kushta is a well-established dosage form of Unani medicine and is supposed to be very effective in view of its small particle size facilitating rapid absorption and quick action compared with other dosage forms, which are coarsely powdered and slowly absorbed. ${ }^{3}$ But, there seems lack of scientific data on the methods of preparation, standardization and toxicity of kushta.

In Unani medicine, toxicity studies are not being conducted in a well organized manner as is carried out in modern medicine, rather toxicity of a drug is denoted merely under the heading of Mazarrat (toxic effects) observed after giving a certain dose level directly on human being, which does always not give precise results and leaves behind a lot of variations in the dose of toxic drugs.

Apart from its use in varied fields, Arsenic trioxide is also used as therapeutic agent for centuries $^{4}$ and is still in use in Unani medicine. ${ }^{3,5}$ Crude arsenic has extensively been studied for its toxicity, ${ }^{6-8}$ but very few scientific reports are available on its kushta form. In view of absence of sufficient data on chronic toxicity of Kushta Sammulfar (KSF) and being a new dosage form, we selected it for chronic toxicity study using standard parameters prescribed for chronic toxicity of drugs. The data were analyzed by appropriate statistical tests to observe any significant variation $(\mathrm{P}<0.05)$ in different groups to see the relative toxicity.

The research protocol was approved by Institutional Animals Ethics Committee (IAEC) of National Institute of Unani Medicine (NIUM), Bangalore, India (vide Reg. 953/C/06/CPCSEA), April 2011. A voucher specimen was submitted to the department of Ilmul Advia (Pharmacology), NIUM.

\section{Materials and Methods}

\section{Materials}

Arsenic trioxide $\left(\mathrm{As}_{2} \mathrm{O}_{3}\right)$ was procured from Nice Pvt. Ltd., Kerala, India. Alum was purchased from local market of Bangalore.

\section{Preparation of the test drug}

KSF was prepared following the method described in National Formulary of Unani medicine. ${ }^{5}$ In the calcination process, Boota and Gile-Hikmat are assumed essential. Boota is a heatproof clay bowl in which drug, which is to be calcined, is kept and the bowl is then covered with
Correspondence: Abdul Wadud, National Institute of Unani Medicine, Kottigepalya, Magadi Main Road, Bangalore, 560091, India.

Tel. +91.08023584260 (Office) - +91.09916608881 (Mobile) - Fax: +91.08023584180

E-mail: drwadud87@gmail.com

Key words: Unani medicine, Kushta, arsenic, toxicity.

Acknowledgments: the authors are thankful to the authorities of National institute of Unani Medicine, Bangalore for providing facilities for experimentation and financial assistance.

Received for publication: 29 0ctober 2012. Accepted for publication: 26 February 2013.

This work is licensed under a Creative Commons Attribution NonCommercial 3.0 License (CC BYNC 3.0).

(C) Copyright A.P. Ansari, et al., 2013

Licensee PAGEPress, Italy

Journal of Xenobiotics 2013; 3:e3

doi:10.4081/xeno.2013.e3

another bowl of similar dimension. Gil-e-Hikmat is the process of application of specific semi solid material made of moist clay and dry cotton wool pounded together till they are mixed well and applied around the bowl especially at the junction of the edges of the two bowls to make the material airtight. Arsenic trioxide and alum were taken in the ratio of $1: 2$ and put in the Boota. A $2 \times 2 \times 2$ cu feet pit was dug and the Boota was placed inside the heap of $2.5 \mathrm{~kg}$ of cow dung cakes placed in the pit. Over it, $2.5 \mathrm{~kg}$ of cow dung cakes were again placed so that the Boota would remain in the middle. The cakes were then ignited. The Boota was taken out of the pit after all the cakes were ignited and the fire cooled down and opened cautiously so as to separate the Kushta easily. The Kushta was pounded manually, weighed and preserved in sterilized glass tubes with airtight lids.

\section{Dose of the test drug}

The effective dose $\left(\mathrm{ED}_{50}\right)$ of KSF in humans has been described in Unani literature as 10-15 mg. ${ }^{5}$ The dose for Wistar rats was calculated by the conversion factor of 7 and was found to be $1.75 \mathrm{mg}^{-1} \mathrm{~kg}^{9}{ }^{9}$

\section{Experimental animals}

Forty healthy Wistar rats of either sex; weighing 150-250 g; 2-3 months of age were used. The animals were divided into four groups of ten animals each. ${ }^{10}$ The animals were kept under standard laboratory conditions. They were housed in polypropylene cages at $23-30^{\circ} \mathrm{C}$ and kept on $12 \mathrm{~h}$ light and dark cycle and had free access to feed and water. 


\section{Experimental design}

The study was carried out according to the methods of Gupta et al., ${ }^{11}$ Ghosh $^{12}$ and Klaassan. ${ }^{10}$ Three dose levels of test drug were given to three groups of rats. First group received five times $\mathrm{ED}_{50}$, second group 10 times $\mathrm{ED}_{50}$ and the third group 15 times $\mathrm{ED}_{50}$, for three months. Fourth group which served as control received normal saline (NS). After three months, blood was collected for studying hematological parameters viz. hemoglobin estimation, red blood cells (RBC) count, total lymphocyte count (TLC), differential lymphocyte count (DLC), biochemical parameters viz. estimation of blood glucose, serum glutamic oxaloacetic transaminase (SGOT), serum glutamic pyruvate transaminase (SGPT) and serum creatinine. Liver and kidney were preserved for histopathology. ${ }^{11}$ Parameters for observing signs of toxicity such as change in body weight, skin color, motor activities, food intake, weight of vital organs like liver and kidney and gross changes in them were considered. ${ }^{10,12}$ The test drug was given orally in the suspension of 5\% gum acacia once in a day, in the morning. The groups and treatment regimen used are:

- Group I (plain control): treated with NS as vehicle in the dose of $5 \mathrm{~mL} / \mathrm{kg}^{13}$

- Group II (KSF-I): received Kushta Sammulfar in the dose of $8.75 \mathrm{mg}^{-1} \mathrm{~kg}$ (5 times of $\left.\mathrm{ED}_{50}\right)$;

- Group III (KSF-II): received Kushta Sammulfar in the dose of $17.50 \mathrm{mg}^{-1} \mathrm{~kg}(10$ times of $\mathrm{ED}_{50}$ );

- Group IV (KSF-III): received Kushta Sammulfar in the dose of $26.25 \mathrm{mg}^{-1} \mathrm{~kg}$ (15 times of $\left.\mathrm{ED}_{50}\right)$. ${ }^{11}$

\section{General observations}

Body weight of the animals was taken every 14 days. ${ }^{12}$ Food intake was measured, periodically by giving known amount of diet to the animals, daily. Early in the morning, the feed was reweighed and the amount consumed was calculated by difference..$^{14}$ General behavior, skin color, skin pigmentation, body hair loss, palpable mass, motility, tremor and convulsions ${ }^{15}$ were observed every 14 days. ${ }^{10}$

\section{Hematology, biochemistry and histopathology}

At the end of the experiment, all animals were killed after $12 \mathrm{~h}$ fasting by over dosing of thiopental sodium. Blood was collected at the end of the experiment through heart puncture for hematology and biochemistry. Liver and kidney were weighed, examined grossly and microscopically.

\section{Hematology}

Hemoglobin was estimated by Sahli's method. RBC and white blood cells were counted by Improved Neubauer Haemocytometer. DLC was done by the method described by Chatterjee. ${ }^{16}$

\section{Biochemistry}

Various biochemical tests ${ }^{10}$ were done by auto analyzer (Star 21 Plus). Blood sugar was estimated by GOD-POD, end point method. SGOT was estimated by UV Kinetic (IFCC) method. SGPT was estimated by UV Kinetic (IFCC) method. Blood urea was estimated by Urease/ GLDH method. Serum creatinine was estimated by Picrate method.

\section{Histopathology}

Liver and kidney were preserved into $10 \%$ formalin buffer overnight, dehydrated and finally embedded in paraffin through histokinet processing. Sections of 5 - $\mu \mathrm{m}$ thickness were cut, stained with routine hematoxylin and eosin..$^{17,18}$ Histopathological changes were seen under a binocular microscope.

\section{Analysis of data}

The data were expressed as mean \pm SEM and the values for the test and control groups were compared by using one-way analysis of variance (ANOVA) followed by different multiple comparison tests. The significance level was considered $(\mathrm{P}<0.05)$.

\section{Results}

\section{General observation}

The animals of all groups showed slight weight gain throughout the experiment, which was not significant statistically. Food intake was found significantly increased in KSF-I $(\mathrm{P}<0.05)$ and KSF-II $(\mathrm{P}<0.01)$. Before weighing the organs, gross examination did not show any changes in any group. The effect on kidney and liver weight was also found non significant statistically. Relative liver weight in control, KSF-I, KSF-II and KSF-III was found to be $3.4 \pm 0.085$, $3.7 \pm 0.086,3.6 \pm 0.079$, respectively. Relative kidney weight (RKW) in control, KSF-I, KSF-II and KSF-III, was found to be $0.54 \pm 0.014,0.46 \pm 0.012$, $0.42 \pm 0.017,0.48 \pm 0.019 \%$, respectively. The RKW was found significantly decreased in KSF-II $(\mathrm{P}<0.01)$. The low and moderate doses of KSF produced mild to moderate diarrhea, whereas the higher dose produced severe diarrhea. All animals were ultimately recovered from diarrhea after 42 days of the experiment. Body hair loss was seen in the neck region in all the test groups from third observation of the experiment except KSF-I. The hair loss gradually increased throughout the experiment. In KSF-II mild hair loss was observed in 2 out of 10 animals. In KSFIII severe hair loss was seen in 5 out of 10 animals. Motility of animals of test groups was found increased throughout the experiment as compared to control group.

\section{Hematology}

Significant increase in TLC was found in KSFII $(\mathrm{P}<0.05)$ as compared to control group. The hemoglobin level increased significantly in KSFII $(\mathrm{P}<0.001)$ as compared to control group (Table $1)$.

\section{Biochemistry}

Blood sugar level increased significantly in all the test groups $(\mathrm{P}<0.001)$ except KSF-I. SGOT increased significantly in KSF-III $(\mathrm{P}<0.01)$. SGPT significantly increased in KSF-III $(\mathrm{P}<0.05)$ as compared to control group. Blood urea increased significantly in KSF-II $(\mathrm{P}<0.05)$, KSFIII $(\mathrm{P}<0.05)$. Serum creatinine level was found

Table 1. Hematological changes produced by Kushta Sammulfar.

\begin{tabular}{|c|c|c|c|c|c|c|c|}
\hline \multirow[t]{2}{*}{ Groups } & \multirow[t]{2}{*}{ Hb (gm\%) } & \multirow[t]{2}{*}{$\mathrm{RBC}(\mathrm{m} / \mathrm{cu})$} & \multirow[t]{2}{*}{ TLC/(cu.mm) } & \multicolumn{4}{|c|}{ DLC (\%) } \\
\hline & & & & Poly & Lymph & Eosin & Mono \\
\hline Control & $9.8 \pm 0.63$ & $3.8 \pm 0.15$ & $2700 \pm 93.54$ & $56.7 \pm 2.96$ & $39.7 \pm 2.83$ & $2.6 \pm 0.33$ & $2.1 \pm 0.37$ \\
\hline KSF-I & $11.54 \pm 0.3$ & $2.67 \pm 0.3$ & $1939 \pm 176.73$ & $52.7 \pm 3.41$ & $43.6 \pm 2.99$ & $3.0 \pm 0.44$ & $2.1 \pm 0.27$ \\
\hline KSF-II & $14.26 \pm 0.57^{*}$ & $4.84 \pm 0.3$ & $3525 \pm 269.80^{* *}$ & $54.2 \pm 2.44$ & $40.6 \pm 2.47$ & $3.9 \pm 0.43$ & $2.0 \pm 0.25$ \\
\hline KSF-III & $11.17 \pm 0.24$ & $4.69 \pm 0.3$ & $2980 \pm 144.99$ & $52.6 \pm 2.28$ & $41.6 \pm 2.00$ & $4.0 \pm 0.21$ & $2.3 \pm 0.30$ \\
\hline
\end{tabular}

$\mathrm{Hb}$, hemoglobin; RBC, red blood cells; TLC, total lymphocyte count; DLC, differential lymphocyte count; KSF, Kushta Sammulfar. Values are mean \pm SEM, "P $<0.001$, " $\mathrm{P}<0.05$, compared with respect to control. 
significantly increased in KSF-I $(\mathrm{P}<0.001)$, KSFIII $(\mathrm{P}<0.001)$, as compared to control group. Detailed results are shown in Table 2.

\section{Histopathology}

Histopathology of liver of control group showed normal structure (Figure 1). No evidence of hepatitis was observed in the KSF-I (Figure 2), however, mild congestion was observed in central vein, hepatic vein and portal triad. Few hepatocytes were swelled up slightly. Few inflammatory cells were seen in portal triad area. Mild to moderate congestion was observed in central vein, hepatic vein and portal triad, in KSF-II and KSF-III. Capsule in KSF-II was found normal but thickened in KSF-III (Figures 3 and 4).

Normal capsule and normal glomeruli were observed in KSF-I. The tubules were lined by intact lining epithelial cells. Mild vascular congestion was observed. Mild interstitial edema and occasional inflammatory cells were seen in interstitial spaces. In the KSF-II studies showed normal capsule and normal glomeruli. The tubules were damaged occasionally. Moderate vascular congestion, mild interstitial edema and occasional inflammatory cells were seen in interstitial spaces of kidney. In the KSF-III section showed normal capsule, while moderate degree of glomerular congestion was seen. Mild to moderate tubular damage was observed. Severe degree of vascular congestion, mild interstitial edema and occasional inflammatory cells were seen in interstitial spaces (Figures 5-8).

\section{Discussion}

No data are available on chronic toxicity of kushta Sammulfar to compare our findings; hence results of earlier studies carried out on crude arsenic may differ from our findings, even though we have tried to compare our findings with the studies carried out on crude arsenic as in calx too there remain some elemental parts. In a study on chronic toxicity of crude arsenic carried out in rats at dose $1.7 \mathrm{mg} / \mathrm{kg}$ (12 h) for 90 days, no change in the body and organ weight was recorded. ${ }^{19}$ In our study, too, no significant changes were observed. But increase in relative weight of liver of KSF-I suggested hypertrophy of the hepatic cells probably because liver tends to accumulate arsenic with repeated exposures over periods of months or years as shown by some studies. Some studies also revealed that arsenic causes hepatomegaly in $77 \%$ of patients after chronic exposure. ${ }^{4}$ Chen et al. (2004) studied the effects of arsenic in mice liver and concluded that chronic oral inorganic arsenic exposure caused cellular hypertrophy and steatosis. ${ }^{20}$ Similarity between the findings of our study and previous studies, is suggestive of some degree of toxicity over prolong use of arsenic irrespective of its form. Significant reduction in RKW in KSFII $(\mathrm{P}<0.05)$ indicated mild renal atrophy, which may be due to injurious effect of the test drug as inorganic arsenic accumulates in the kidney after repeated exposure and it is a major route for the excretion of arsenic. ${ }^{21}$ Presence of elemental arsenic in kushta may have caused this atrophy. The average daily food intake significantly increased in KSF-I $(\mathrm{P}<0.05)$ and KSF-II $(\mathrm{P}<0.01)$ in the beginning of the experiment, which may be due to hyperglycemia, observed in our study. Arsenic is more likely than other heavy metals to produce a dramatic gastro enteric picture after ingestion. In acute arsenic poisoning, bloody rice water diarrhea is often observed. ${ }^{22,23}$ Acute high exposure as well as longer term lower dose exposures of arsenic can produce diarrhea. ${ }^{24-26}$ Though, diarrhea was observed in our study in all the test groups but no bloody diarrhea at any dose level in any group was observed. This may be suggestive of mild to moderate gastroenteritis produced by calx form, which is less harmful than crude arsenic. Skin is a major target organ of arsenic toxicity. Many skin lesions such as hyper pigmentation, hypo pigmentation, hyperkeratosis and parakeratosis are usually seen in humans after chronic exposure to arsenic. ${ }^{27,28}$ Interestingly, the hallmark dermal lesions associated with human oral exposures to arsenic have not been found to occur in experimental animals. We too did not find dermal lesions in the animals in our study. Body hair loss after ingestion of arsenic is an indicator of toxicity. Hair loss was seen in the neck region in all groups except KSF-I from the third observation, which was gradually increased throughout the study. Excessive hair loss was seen in KSF-III. Some studies suggested that even small dose of arsenic for prolong use can cause hair loss. ${ }^{24,29}$ Our findings suggested that arsenic can cause hair loss in any form, if used for long. In our study, motility was increased in all the test groups which validate the claim of Unani medicine that Kushta Sammulfar possesses Muharrik-e-Asab (nerve stimulant effect) ${ }^{30,31}$ however this claim is not supported by any scientific report.

Hematology is also good parameter for the assessment of toxicity. In our study, RBC count slightly increased in KSF-II and KSF-III. It may be due to Muqauwi-e-Dam (hemopoietic) effect of Kushta Sammulfar. ${ }^{32}$ Hemoglobin level increased slightly in KSF-I, and III and markedly in KSF-II $(\mathrm{P}<0.001)$, which may be due to increase in RBC count. However, studies have shown to produces anemia after chronic exposure of arsenic, ${ }^{20,23,29}$ but it may be because of kushta form of arsenic which contains less amount of elemental arsenic not causing massive destruction of RBCs. Our findings are in consonance with the reports of Unani physicians. $^{32}$ TLC count slightly decreased in KSF-I, while remarkably increased in KSF-II $(\mathrm{P}<0.01)$ as compared to control group found that the TLC count decreased when mice were given higher dose of arsenic. It may be due to apoptotic effect of arsenic on plasma cells. ${ }^{33}$ In DLC, polymorph count was slightly decreased in KSF-I, II, III. Granulocytopenia is a common effect of arsenic poisoning and is reported as resultant of acute, intermediate and chronic oral exposures. This effect might be due to cytotoxic effect of arsenic on the polymorph cells. ${ }^{20}$ The lymphocyte count was slightly increased in all the test groups as compared to control. This effect might be due to counteract poisonous effect of Kushta Sammulfar. Several studies related to animals as well as humans have shown that long term arsenic exposure can cause diabetes mellitus. ${ }^{4,23,33-36}$ In our study, blood sugar level increased significantly $(\mathrm{P}<0.001)$ in all test groups except KSF-I. Hyperglycemias may be due to islet cells toxicity because arsenic administration is reported to cause severe damage of islet cells..$^{33}$ In male Wistar rats, exposed to 1.7 ppm of arsenite orally for 90 days, the pancreas pathology included the absence of insulin immunolabel in the Beta cells and a discontinuous peripheral pattern of glucagon. ${ }^{35}$ A study indicated that sub chronic exposure to $\mathrm{As}_{2} \mathrm{O}_{3}$

Table 2. Biochemical changes produced by Kushta Sammulfar.

\begin{tabular}{lccccc} 
Groups & $\begin{array}{c}\text { SGOT } \\
(\mathrm{U} / \mathrm{L})\end{array}$ & $\begin{array}{c}\text { SGPT } \\
(\mathrm{U} / \mathrm{L})\end{array}$ & $\begin{array}{c}\text { Blood urea } \\
(\mathrm{mg} / \mathrm{dL})\end{array}$ & $\begin{array}{c}\text { Serum creatinine } \\
(\mathrm{mg} / \mathrm{dL})\end{array}$ & $\begin{array}{c}\text { Blood sugar } \\
(\mathrm{mg} / \mathrm{dL})\end{array}$ \\
Control & $115.98 \pm 40.39$ & $69.43 \pm 20.99$ & $47.74 \pm 2.57$ & $0.344 \pm 0.04$ & $149.54 \pm 15.28$ \\
KSF-I & $101.53 \pm 16.98$ & $62.15 \pm 14.00$ & $51.04 \pm 2.52$ & $0.635 \pm 0.05^{*}$ & $144.65 \pm 12.23$ \\
\hline KSF-II & $255.17 \pm 40.21$ & $93.55 \pm 6.60$ & $75.83 \pm 4.12^{* *}$ & $0.472 \pm 0.02$ & $281.86 \pm 20.32^{*}$ \\
KSF-III & $354.95 \pm 17.04^{* * *}$ & $118.13 \pm 9.49^{* *}$ & $78.16 \pm 6.98^{* *}$ & $0.776 \pm 0.01^{*}$ & $296.67 \pm 14.38^{*}$ \\
\hline
\end{tabular}

SGOT, serum glutamic oxaloacetic transaminase; SGPT, serum glutamic pyruvate transaminase; KSF, Kushta Sammulfar. Values are mean \pm SEM, ${ }^{*} \mathrm{P}<0.001$, " $\mathrm{P}<0.05$, ${ }^{* * *} \mathrm{P}<0.01$, compared with respect to control. 
induces oxidative stress and oxidative damage in pancreas..$^{36}$ Our findings are similar to previous studies.

Arsenic is known to produce disturbance in liver function; therefore, SGOT and SGPT may be reliable determinants of liver parenchymal injury. Increase in plasma SGOT and SGPT may be mainly due to the leakage of these enzymes from the liver cytosol into the blood stream. ${ }^{36}$ In our study, SGOT increased significantly in KSFIII $(\mathrm{P}<0.01)$, SGPT was also increased significantly in KSF-III $(\mathrm{P}<0.05)$. These findings reveal that Kushta Sammulfar also causes hepatotoxicity, if used for long. In low dose of KSF, SGOT and SGPT did not increase indicating that kushta is not injurious for liver in low dose. However, further follow up is suggested for 120 days or more to rule out the chronic use of these arsenic formulations and effect on various organs evaluated using analytical techniques for estimation of free arsenic and arsenic trioxide.

Since, arsenic and its various preparations are reported to cause renal damage ${ }^{19,37}$ therefore, renal function test may be a good pointer of arsenic poisoning. Production of oxygen free radicals by arsenic induces tubular necrosis, which in turn increases tubular permeability resulting in diffusion and back leak of the filtrate across the tubular basement membrane back into the interstitium and circulation leading to an apparent decrease in glomerular filtration rate. Under these circumstances, back leak of filtrate results in decreased excretion and increased retention of nitrogenous waste i.e. urea in serum. ${ }^{37}$ In our study, blood urea was significantly increased in KSF-II $(\mathrm{P}<0.05)$, III $(\mathrm{P}<0.05)$. It may be calculated that Kushta Sammulfar in moderate to high dose is toxic to the kidney. Serum creatinine was found significantly increased in KSF-I $(\mathrm{P}<0.001)$, KSF-III $(\mathrm{P}<0.001)$, showing almost all dose level toxic to the kidney.

Histopathological study of liver clearly demonstrated that the KSF produced toxicity to the liver as chronic hepatitis. These features were dose dependent as in low dose of KSF caused mild congestion in central vein, hepatic vein and portal triad, which may be due to prolonged use, no liver hyperplasia, adenomas, or cancer lesions were found. Similarly, the histopathological study of kidney demonstrated that the KSF produced toxicity to the renal tissues and produced the features of chronic nephritis with graded doses. Several clinical studies have suggested that arsenic causes severe hepatic and renal damage even prolong use can cause cancer of those organs. ${ }^{38}$ In the 1980 s, several studies reported on the carcinogenicity of inorganic arsenic, in hamster after intratracheal instillation, ${ }^{39}$ in rats' urinary bladder. ${ }^{40}$ Some studies have suggested that an animal model is still needed for completely proving and understanding the carcinogenic effect of arsenic. However, there have been several positive reports on the

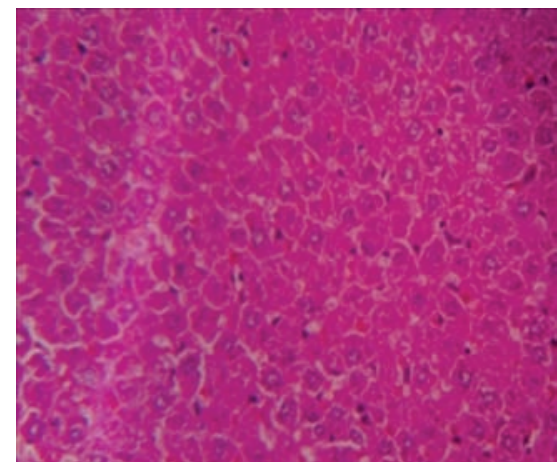

Figure 1. Liver of control group showing normal structure.

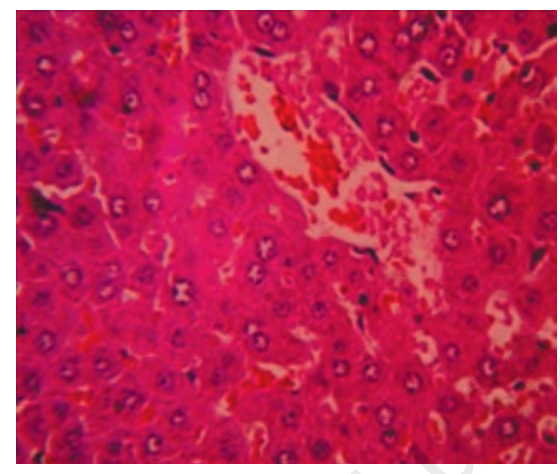

Figure 2. Liver of Kushta Sammulfar-I showing mild congestion in central vein, hepatic vein and portal triad.

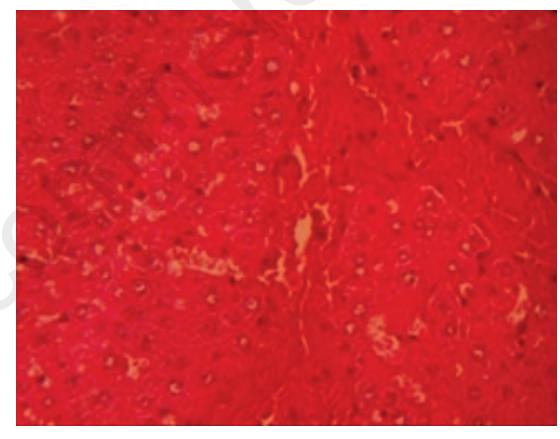

Figure 3. Liver of Kushta Sammulfar-II showing moderate congestion in central vein, hepatic vein and portal triad.

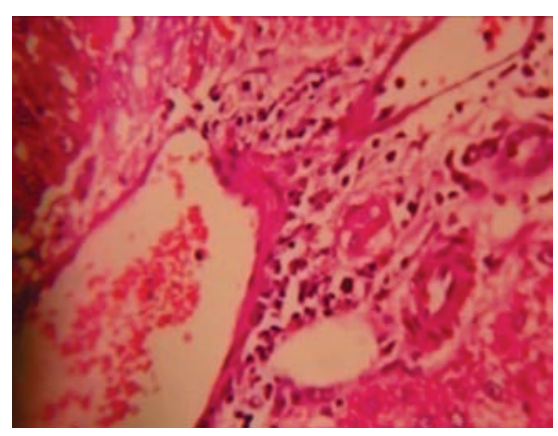

Figure 4. Liver of Kushta Sammulfar-III showing moderate congestion in central vein hepatic vein, portal triad and lymphatic infiltration.

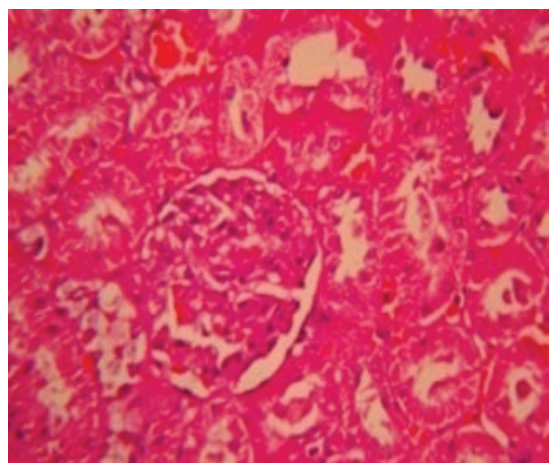

Figure 5. Kidney of control group showing normal capsule and glomeruli.

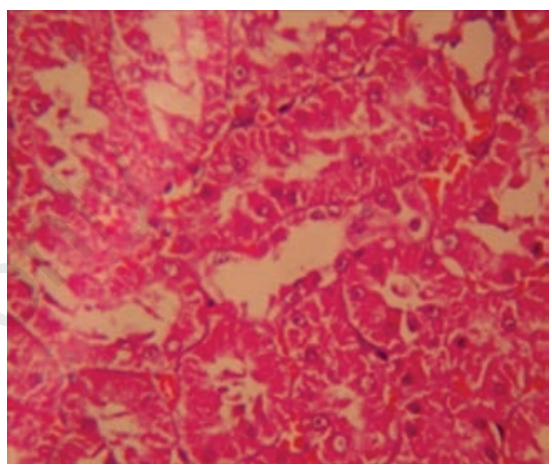

Figure 6. Kidney of Kushta Sammulfar-I showing normal capsule and glomeruli.

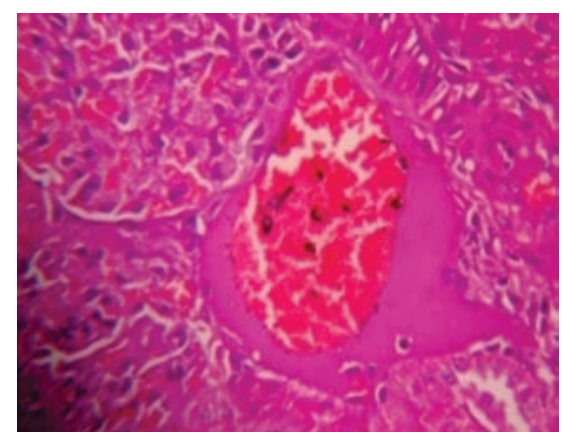

Figure 7. Kidney of Kushta Sammulfar-II showing tubular damage, vascular congestion, mild interstitial edema and occasional inflammatory cells.

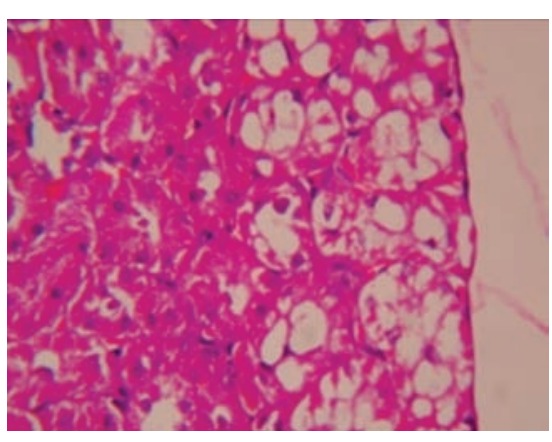

Figure 8. Kidney of Kushta Sammulfar-III showing inflammatory cells, glomerular congestion, severe vascular congestion, mild interstitial edema and inflammatory cells. 
carcinogenicity of arsenic in animal models. ${ }^{39}$ The mild to moderate toxic effects of calx form of arsenic may be due to presence of elemental arsenic in oxide form as in our previous study we found $6.388 \pm 0.711 \mathrm{ppm}$ elemental arsenic in KSF estimated by atomic absorption spectrophotometery. ${ }^{41}$

\section{Conclusions}

KSF produced dose dependent toxicity. KSF-1, i.e. low dose of KSF did not produce remarkable toxic effects. Mild to moderate toxicity was observed in KSF-II and KSF- III. Though, liver and kidney tissues were not markedly damaged, but in view of risk benefit ratio (more risk than benefit) and low safety margin, use of KSF particularly prolong use in human should be warned as self medication must be avoided, as it was found moderately toxic in rats. The study also validated the claim of Unani physicians regarding the use of KSF in low dose and a gap of certain period for the next use.

\section{References}

1. Irshad S, Wadud A, Jahan N, Sofi G, Ahmad G. Comparative toxicity studies of various dosage forms of Sammul far (Arsenic trioxide) in mice. IJTK 2011;10:721.

2. Aziz N, Gilani AH, Rindh MA. Kushta (s): Unique herbo-mineral preparation used in South Asian traditional medicine. Med Hypothesis 2002;59:468-72.

3. Anonymous. Hamdard pharmacopoeia of Eastern Medicine. New Delhi: Sri Satguru Publications; 1997. pp 222-3, 228, 302.

4. Pimparkar BD, Bhave A. Arsenicosis: review of recent advances. J Assoc Phys India 2010;58:617-29.

5. CCRUM, Ministry of Health and Family Welfare, Govt. of India. National formulary of Unani medicine, Part I. New Delhi: CCRUM; 2006:p 76.

6. Jack CN, Wang J, Sharim A. A global health problem caused by arsenic from natural sources. Chemosphere 2003;52:1353-9.

7. Saha JC, Dikshit AK, Bandyopadhyay M. A review of arsenic poisoning and its effects on human health. Clin Rev Environ Sci Technol 1999:29:281-313.

8. Verma RJ, Vasu A, Saiyed AA. Arsenic toxicity in mice and its possible amelioration. $\mathrm{J}$ Environ Sci 2004;16:447-53.

9. Freirich EJ, Gehan EA, Rall DP, Schmidt LH, Skipper HE. Quantitative comparison of toxicity of anti cancer agents in mice, rat, hamster, dog, monkey and man. Cancer Chemother Report 1966;50:219-44.
10. Klassan CD. Casarett and Doull's toxicology - The basic science of poisons. $7^{\text {th }}$ ed. New York, NY: McGraw-Hill, Inc.; 2008. pp 31, 32, 938.

11. Gupta S, Shukla R, Prabhu KM, Aggrawal S, Rusia U, Murthy PS, et al. Acute and chronic toxicity studies on partially purified hypoglycaemic preparation from water extract of bark of Ficus bengalensis. Indian J Clin Biochem 2002;17:58-63.

12. Ghosh MN. Fundamentals of experimental pharmacology. $4^{\text {th }}$ ed. Kolkata: Hilton and Company; 2008. p 177.

13. Kumarnsit E, Keawpradub N, Vongvatcharanon U, Sawangjaroen K, Govitrapong $P$. Suppressive effects of dichloromethane fraction from the Areca catechu nut on naloxone-precipitated morphine withdrawal in mice. Fitoterapia 2005;76:534-9.

14. Ulman EA, Compton D, Kochaneck J. Measuring food and water intake in rats and mice. ALN Magazine 2008;17-20.

15. Siddiqui R, Vohora D, and Vohora S. Proconvulsant effects of calcined arsenic preparation used in Unani Medicine. Indian J Pharmacol 1999;31:150-2.

16. Chatterijee CC. Human physiology. Vol. 1. Kolkata: Medical allied Agency; 2004. pp 174-6.

17. Acharya S, Chaudharim S, Chatterjee S, Kumar P, Begum Z, Dasgupta S, et al. Immunological profile of arsenic toxicity: a hint towards arsenic-induced carcinogenesis. Asian Pacific J Cancer Prevent 2010;11:479-90.

18. Ozguner M, Sayin N. Histological changes in rat liver after chronic iron-sorbitol overload. J Ankara Med School 2002;24:49-54.

19. Vega JA, Soto CA, Luz C, Pena, S, VizcayaRuiz A, Del Razo L, et al. Diabetogenic effects and pancreatic oxidative damage in rats sub chronically exposed to arsenite. Toxicol Lett 2006;160:135-42.

20. Cohen SM, Ohnishi T, Arnold LL, Le XC. Arsenic-induced bladder cancer in an animal model. Toxicol Appl Pharmacol 2000;222:258-63.

21. Mandal BK, Suzuki KT. Arsenic round the world: a review. Talanta 2002;58:201-35.

22. Ratnaike RN. Acute and chronic arsenic toxicity. Postgrad Med J 2003;79;391-6.

23. Mazumdar DN. Chronic arsenic toxicity and human health. Indian $\mathrm{J}$ Med Res 2008;128:436-47.

24. Prasad B. Principles and practice of medicine. New Delhi: Jaypee Brothers; 1997. pp 871-2.

25. Ledingham JGG, Warrell DA. Concise Oxford textbook of medicine. New York: Oxford University Press; 2000. p 1863.

26. ATSDR. Sudbury area risk assessment. Vol II, Appendix AI: Detailed toxicological profile of arsenic. Atlanta, GA: Agency for Toxic
Substances and Diseases Registry; 2008. pp 55-56.

27. Pritchard JD. HPA compendium of chemical hazards (inorganic arsenic). Version 3. London: Health protection agency; 2008. pp 5-29. Available from: http:/www.hpa.org.uk/ Topics/ChemicalsAndPoisons/Compendium OfChemicalHazards/

28. Singh N, Kumar D, Sahu AP. Arsenic in the environment: effect on human health and possible prevention. J Environ Biol 2007; 28:359-65.

29. Goodman A, Gilman A, eds. The pharmacological basis of therapeutics. $10^{\text {th }}$ ed. New York, NY: McGrew-Hill; 2001:1862-4.

30. Kabeeruddin HM. Ilmul Advia Nafeesi. New Delhi: Aijaz Publishing House; 2007. pp 2945.

31. Qarshi HMH. Silk-e-Marwareed. New Delhi: Aijaz Publishing House; 1996:106-8.

32. Kabeeruddin HM. Kitab-al-Taklees. New Delhi: Central Council for Research in Unani Medicine: YNM; 2009.

33. Yasmin S, Das J, Stuti M, Rani M, D’Souza D. Sub chronic toxicity of arsenic trioxide on swiss albino mice. Int $\mathrm{J}$ Environ Sci 2011;1:1640-7.

34. Acien AN, Silbergeld EK, Streeter RA, Clark JM, Burke TA, Gullar E, et al. Arsenic exposure and type 2 diabetes: a systematic review of the experimental and epidemiologic evidence. Environ Health Perspect 2006;114:641-8.

35. Chiu H, Chang C, Tsai S, Yang C. Does arsenic exposure increase the risk for diabetes mellitus. J Occp Environ Med 2006; 48:63-7.

36. Vigo J, Ellzey J. Effects of arsenic toxicity at cellular level - a review. Tex J Micros 2006;37:45-9.

37. Saxena PN, Anand S, Saxena N, Bajaj P. Effect of Arsenic trioxide on renal functions and its modulation by Curcuma aromatica leaf extract in albino rat. J Environ Biol 2009;30:527-31.

38. Wang JP, Qi L, Moore MR, Ng JC. A review of animal models for the study of arsenic carcinogenesis. Toxicol Lett 2002;133:17-31.

39. Hughes MF. Arsenic toxicity and potential mechanism of action. Toxicol Lett 2002; 133:1-16.

40. Cohen SM, Ohnishi T, Arnold LL, Le XC. Arsenic-induced bladder cancer in an animal model. Toxicol Appl Pharmacol 2007; 222:258-63.

41. Shamim I, Wadud A, Jahan N, Sofi G, Ahmad G. Preparation of Kushta sammulfar (calx of Arsenic) by muffle furnace using the temperature pattern extrapolated from classical method of its preparation as practiced in Unani Medicine. Unani Medicus 2011;1:36-9. 


\section{Bioremediation of refinery wastewater using immobilised Burkholderia cepacia and Corynebacterium sp and their transconjugants}

\author{
Abdullahi Taiwo Ajao, ${ }^{1}$ S.E. Yakubu, ${ }^{2}$ \\ V.J. Umoh, ${ }^{2}$ J.B. Ameh² PROVIDE \\ AUTHORS' FULL NAMES
}

${ }^{1}$ Department of Biology, Institute of Basic and Applied Sciences, Kwara State Polytechnic, Ilorin; ${ }^{2}$ Department of Microbiology, Ahmadu Bello University, Zaria, Nigeria

\section{Abstract}

When oil spill occurs, it poses serious toxic hazards to all forms of life. Mixed culture of Burkholderia cepacia and Corynebacterium sp isolated from refinery sludge using selective enrichment technique was used for bioremediation of refinery wastewater in a laboratoryscale bioreactor. Physicochemical parameters of both raw and treated water were as determined and compared with Federal Environmental Protection Agency (FEPA-limit, Abuja, Nigeria) to asses the efficiency of the bioremediation process. Each of the bacterium was screened for the presence of plasmid DNA and for the involvement or otherwise of plasmid in the bioremediation of wastewater. The immobilised cells showed percentage decrease in chemical oxygen demand (97\%), biochemical oxygen demand (94\%), phenol (98\%), total petroleum hydrocarbon (79\%), oil and grease (90\%) of the refinery waste water after 20 days of treatment while their transconjugants showed the multiplicative effect by achieving the same percentage after 10 days of treatment. Therefore, the findings revealed that bioaugmentation of wastewater using transmissible catabolic plasmid will enhance efficiency of the bioremediation by spreading the plasmid among indigenous microbial community either through horizontal gene transfer or transformation.

\section{Introduction}

Wastewater released by petrochemical industries are characterized by the presence of large quantity of polycyclic and aromatic hydrocarbons, phenols, metal derivatives, surface active substances, sulphides, naphethylenic acids and other chemicals. ${ }^{1,2}$

The process of refining crude oil consumes large amounts of water. Consequently, significant volumes of wastewater are generated. ${ }^{3}$ Coelho et $a l^{3}{ }^{3}$ reported that the volume of refinery effluent generated during processing is 0.4-1.6 times the amount of the crude oil processed. Thus, based on the current yield of 84 million barrels per day (mbpd) of crude oil, a total of 33.6 mbpd of effluent is generated globally. ${ }^{4}$

Mobile genetic elements (MGEs) that encode catabolic genes are considered to play a major role in the adaptation of microbial populations to xenobiotic organic compounds, through either by spreading the genes in a community and thereby increasing the diversity of organisms able to metabolise these compounds, or by rearranging and combining pre-existing genes or gene fragments from different microorganisms to constitute a new pathway dealing with a new compound. Such catabolic mobile elements include plasmids, transposable elements and elements using phage-like integrases..$^{5,6}$

Effluents from the oil industry will continually be produced and discharged into the world's main water bodies. However, these pollutants pose serious toxic hazards to the environment. Petroleum refinery effluent can vary greatly depending on the type of oil being processed, the plant configuration, and operation procedures? ${ }^{7}$. They enter into waterways and have negatives impact on the aquatic and terrestrial eco-systems.

Bioremediation has long been applied as a treatment technology that is cost-effective, ecologically friendly and efficient for the decontamination of hydrocarbon polluted soils. ${ }^{8-15}$

There is a need for the survival of inoculum and to remain physiologically stable for a very long time in a pollutant, the inoculation of strains with MGEs that encode the relevant genetic information and their subsequent genetic horizontal transfer to one or various well established and competitive indigenous bacterial populations of an ecosystem is an alternative strategy. In this case, the survival of the introduced donor strain is no longer needed once the catabolic genes are transferred and expressed in the indigenous bacteria within the ecosystem. ${ }^{16}$

The immense potential of such microorganisms to degrade petroleum hydrocarbon does not depend solely upon the wealth of catabolic enzymes that these organisms possess, but also upon their capacity for adaptive change. ${ }^{17}$ The present work identified mixed culture of crude oil degrading Burkholderia cepacia and Corynebacterium sp isolated from refinery oil sludge and their ability to transfer plasmid to the indigenous bacteria in the ecosystem for the preparation of bacterial blend that could be used in bioremediation of refinery waste water.
Correspondence: Abdullahi Taiwo Ajao, Department of Biology, Institute of Basic and Applied Sciences, Kwara State Polytechnic, Ilorin, Nigeria.

E-mail: ajaoabdullahi@yahoo.com

Key words: multiplicative effect, bioaugmentation, transformation, transconjugant, catabolic plasmid.

Acknowledgements: the authors thank Board of Research and Department of Microbiology, Ahmadu Bello University, Zaria for providing funds. Ajao thanks Engr. Alfred U. Amadi, Deputy Manager; process Engineering Dept., Kaduna Refining \& Petrochemical Company (KRPC), Kaduna, Nigeria for his technical assistance.

Received for publication: 9 January 2013.

Revision received: 1 March 2013.

Accepted for publication: 1 March 2013.

This work is licensed under a Creative Commons Attribution NonCommercial 3.0 License (CC BYNC 3.0).

(C) Copyright A.T. Ajao et al., 2013

Licensee PAGEPress, Italy

Journal of Xenobiotics 2013; 3:e4

doi:10.4081/xeno.2013.e4

\section{Materials and Methods}

\section{Collection of the wastewater amples}

The wastewater samples from different concrete wastewater reservoirs in Kaduna Refinery \& Petrochemical Company (KRPC; Kaduna, Nigeria) were collected into four litres plastic bottles and stored in an ice block cooler and transferred to the laboratory immediately for analysis. ${ }^{18,19}$ All the collected samples were preserved in accordance with guidelines and International Standards. The samples collected were analysed for $\mathrm{pH}$, biological oxygen demand $\left(\mathrm{BOD}_{5}\right)$, chemical oxygen demand (COD), total dissolved solids, phenol, oil and grease, sulphide and some selected heavy metals. All other quality assurance and quality control procedure relevant to samples collection, custody and analyses were strictly adhered to for the determination of physicochemical parameters. ${ }^{20-23}$

\section{Immobilization of cells}

Mixed culture of Burkholderia cepacia and Corynebacterium sp that showed degradative potential during mineralization of Bonny Light crude oil were immobilised on agar-agar as follows: agar-agar solution and inoculi for immobilisation were prepared separately as thus; Fifty $\mathrm{mL}$ of each of the inoculi was inoculated into nutrient broth and incubated for $24 \mathrm{~h}$. A 
solution containing 3\% bacteriological agar was dissolve in $0.9 \%$ sodium chloride $(100 \mathrm{~mL})$ in a $250 \mathrm{~mL}$ Erlenmeyer flask, sterilized and cooled to $40-45^{\circ} \mathrm{C}$. The inoculi with optical density (OD) $)_{600 \mathrm{~nm}}=1.0$ which correspond to $10^{9}$ $\mathrm{cfu} / \mathrm{mL}$ was added to the prepared molten agaragar maintained at $40^{\circ} \mathrm{C}$, shaken well for few seconds (without forming foam), poured into sterile flat bottom 4-inch-diameter petriplates, solidification occurred after $10 \mathrm{~min}$. The solidified agar block was cut into equal size cubes, then added to sterile $0.1 \mathrm{M}$ phosphate buffer ( $\mathrm{pH} 7.0)$, and kept in the refrigerator (1 h) for curing. Phosphate buffer was decanted and the cubes were washed with sterile distilled water 3 to 4 times before used. ${ }^{24}$

\section{Bioremediation using immobilized mixed culture}

Initial physicochemical characterization of the refinery wastewater was done.

Two litres of the refinery wastewater supplemented with minimum basal medium in $\mathrm{g} / \mathrm{L}$ [ $\mathrm{NaCl}(0.8) ; \mathrm{MgSO}_{4} .7 \mathrm{H}_{2} \mathrm{O}$ (0.001); $\mathrm{KH}_{2} \mathrm{PO}_{4}(2)$; $\mathrm{NaNO}_{3}$ (2); $\mathrm{CaCl}_{2} \cdot 2 \mathrm{H}_{2} \mathrm{O}$ (0.5); $\mathrm{NaHPO}_{4} \cdot 12 \mathrm{H}_{2} \mathrm{O}$ (2)] was sterilized in an autoclave at $121^{\circ} \mathrm{C}$ for 15 min. One litre of the sterilized wastewater was dispensed into $5 \mathrm{~L}$ bioreactor fitted with air sparger aseptically. Thirty grams each of the immobilized bacterial cells was added..$^{25}$ Physicochemical parameters were determined in triplicate at every five days intervals to monitor the progress of bioremediation for 20 days.

\section{Preparation of crude oil degrading transconjugant culture}

Method of Bathe and Hausner (2010) ${ }^{26}$ was modified and used for the preparation of crude oil degrading transconjugants. This was done to transfer catabolic plasmid from oil degrading host strains to a mixture of non-oil degrading indigenous strains in the oil sludge. Overnight donor cell of mixed culture of Burkholderia cepacia and Corynebacterium sp grown in Luria-Bertani (LB) medium supplemented with $1 \%$ crude oil. Also ten grams of oil sludge was added to $90 \mathrm{~mL}$ of Bushnell-Haas (BH) medium and incubated for $48 \mathrm{~h}$ to obtain oil sludge suspension. Two mL of donor strains was mixed with $2 \mathrm{~mL}$ of pre-grown suspension of oil sludge. Drop of $1 \mathrm{~mL}$ of this mixture was plated on $\mathrm{LB}$ agar plates and incubated at $37^{\circ} \mathrm{C}$ for $24 \mathrm{~h}$ for the conjugation to occur.

The mating spot was scrapped of the agar surface and resuspended the cells in $1 \mathrm{~mL}$ of phosphate buffered saline (PBS), centrifuged and discarded the supernatant. The pellet mixtures were spread on oil agar plates (BH medium supplemented with $2 \%$ crude oil) to select transconjugants.

Prior to mixing of donor and recipient indigenous suspension was unable to grow in oil agar. Transconjugant was selected, purified in PBS and later used for bioremediation process. The colonies on the oil agar were removed and transferred into $1 \mathrm{~mL}$ of PBS, vortex vigorously, centrifuged for $10 \mathrm{~min}$ at 5000 rpm. Pellet was re-suspended again in PBS. The cell pellet was washed twice and resuspended with $\mathrm{BH}$ medium until $\mathrm{OD}_{600}$ was equivalent to 1.0 .

\section{Screening of transconjugant bioremediation capabilities}

Ten grams of wood chips was added to five litres bioreactor fitted with air sparger to serve as biofilm carrier material. One litre of refinery wastewater supplemented with minimum basal medium was transferred to bioreactor. The $10 \%$ of cells of crude oil degrading transconjugant with $\mathrm{OD}_{600 \mathrm{~nm}}=1.0$ which correspond to $10^{9} \mathrm{cfu} / \mathrm{mL}$ was added to the bioreactor control sample contained only the sludge inoculums without culture. Set up was left for 10 days. The following parameter was used for assessment, e.g. COD, oil and grease, phenol, $\%$ oil loss and sulphide.

\section{Plasmid profiling and agar gel electrophoresis}

Plasmid extraction was carried out using the method described by Ojo and Oso (2009) ${ }^{27}$ with slight modification. Pure isolates were inoculated on tars broth and incubated. The grown cells were harvested and suspended in $200 \mu \mathrm{L}$ of solution A [ $100 \mathrm{~mm}$ glucose- $50 \mathrm{~mm}$ tris hydrochloride ( $\mathrm{pH} \mathrm{8)-10} \mathrm{mm} \mathrm{ethylenedi-}$ aminetetraacetic acid (EDTA)] containing 10 $\mathrm{mg}$ tanolysin and incubated for $30 \mathrm{~min}$ at $37^{\circ} \mathrm{C}$ in a dodecyl sulphate in $0.2 \mu \mathrm{L} \mathrm{NaOH}$ was added and the samples were mixed by inverting tubes. Three hundred uL of a $30 \%$ potassium acetate solution ( $\mathrm{pH} 4.8$ ) was added and the samples were mixed by vortexing. The supernatant was removed and extracted once with a phenol - chloroform mixture (1:1) and precipitated with an equal volume of isopropanol. The plasmid DNA was then dissolved in $100 \mu \mathrm{L}$ of tris-EDTA buffer. Electrophoresis of the DNA was carried out on a $0.8 \%$ agarose gel in a $0.5 \times$ concentration of tris-borate-EDTA buffer. After boiling, the solution was allowed to cool $10 \mu \mathrm{L}$ of ethidium bromide was added to the cooled agarose solution. This was poured into a casting tray with a comb placed across its rim to form wells. The gel was allowed to set for $30 \mathrm{~min}$ and the comb was removed. Twenty $\mu \mathrm{L}$ of the plasmid DNA samples were then loaded into the wells after mixing with $2 \mu \mathrm{L}$ of bromophenol blue. A DNA molecular weight marker was also loaded into one of the well. The gels were thereafter electropholesed in a horizontal tank at a constant voltage of $60 \mathrm{v}$ for about $1 \mathrm{~h}$ and $30 \mathrm{~min}$. After electrophoresis, plasmid DNA bands were viewed by fluores- cence of bound ethidium bromide under a short wave ultraviolet light transilluminator and the photograph were taken using a digital camera.

\section{Curing of plasmid}

Curing of plasmid was done to identify the catabolic plasmid encoded in the isolated bacteria. The modified methods ${ }^{28,29}$ were used. A stock solution of $10 \%$ sodium dodecyl sulfate (SDS) was prepared by the addition of $10 \mathrm{~g}$ SDS to $100 \mathrm{~mL}$ of nutrient broth. The $\mathrm{pH}$ was adjusted to 7.8-8.0. The mixture was steamed for $1 \mathrm{~h}$ and kept aside as stock. The overnight cultures of selected isolates in LB were diluted 100 -fold and $0.5 \mathrm{~mL}$ volume of each of the isolates was transferred aseptically into fresh 30 $\mathrm{mL}$ volume of nutrient broth. The cultures were incubated with shaking for $3 \mathrm{~h}$ and SDS stock solution was added to give the required final concentration $1 \%(\mathrm{w} / \mathrm{v})$. The cultures were incubated at room temperature with mild agitation for $72 \mathrm{~h}$. The cells were then tested for crude oil degradation: after transferring 0.5 $\mathrm{mL}$ sample of each of the isolates into nutrient broth supplemented with crude oil $2 \%(\mathrm{w} / \mathrm{v})$, the plasmid content was determined by carrying out the plasmid isolation procedure described above.

\section{Results and Discussion}

The result of both raw and treated kaduna refinery wastewater using immobilised mixed culture of Burkholderia cepacia and Corynebacterium sp. are presented in Table 1 while the result of treated wastewater using transconjugants are shown in Table 2. The $\mathrm{pH}$ values varies between (8.0-6.55) while COD, phenol and oil and grease in raw waste water are $875 \mathrm{mg} / \mathrm{L}, 68.13 \mathrm{mg} / \mathrm{L}$ and $43.20 \mathrm{mg} / \mathrm{L}$ respectively while final level obtained in both immobilised cell treated wastewater and transconjugant treated wastewater are: 25.46 $\mathrm{mg} / \mathrm{L}$ and $68 \mathrm{mg} / \mathrm{L} ;(0.32 \mathrm{mg} / \mathrm{L}$ and $1.06 \mathrm{mg} / \mathrm{L}$; $4.27 \mathrm{mg} / \mathrm{L}$ and $2.53 \mathrm{mg} / \mathrm{L}$, respectively. Result revealed an overall reduction in all the physicochemical parameters below FEPA-Limit. Lead $\left(\mathrm{Pb}^{2+}\right)$ was completely biosorptioned, while nitrate and sulphate were significantly reduced. $\mathrm{BOD}_{5}$ test was found to reduce to (14 $\mathrm{mg} / \mathrm{mL}$ ). Both BOD and COD are useful parameters in determining the relative waste loading and higher degree therefore indices the presence of large amount of organic pollutant and relatively higher level of microbial activities with consequent depletion of oxygen content. ${ }^{30}$ However, nitrate and phosphate are essential nutrients to plants life, but when found in excess quantities, stimulates excessive plant growth leading to potentially toxic algal 
blooms. $^{31}$

The results obtained in the plasmid profiling in Figure 1 showed that both isolates contained plasmid. Plasmids that encode enzymes involved in the transformation of environmental pollutants are known as catabolic plasmids. ${ }^{32}$ The incidence of such plasmids in oil degrading bacteria had been reported by many researchers ${ }^{33}$ reported that the catabolic gene which encode degradation routes of different aromatic and aliphatic hydrocarbons are frequently located on plasmids, although degradative genes can be located on either chromosome or plasmid. ${ }^{34}$ Whyte and colleagues ${ }^{35}$ extracted plasmids from Burkholderia and Corynebacterium strains isolated from oilsludge conferred ability to degrade crude oil in order to confirm whether the observed biodegradation potential in the isolates was plasmid or chromosomal mediated, the cured colony was unable to grow on Bushnell-Haas medium agar with crude oil as sole carbon source, therefore, the total loss of biodegradation ability after plasmid curing shows the involvement of plasmid in catabolic activity of hydrocarbon biodegradation, this indicates that the gene(s) responsible for crude oil degradation might have been cured, thus not allowing the colony to grow in oil agar. ${ }^{36}$

Catabolic pathways, which encoded different aromatic hydrocarbon degradation routes, are frequently located on plasmids, although genes involved in degradation can be located on either chromosomal DNA or plasmid. ${ }^{37}$ Our findings show that the capacity to mineralize crude oil by Burkholderia and Corynebacterium species are plasmid-encoded. Agarose gel electrophoretic separation profiles (Figure 1) of plasmidic DNA isolated from non-cured cultures showed that Burkholderia and Corynebacterium species harboured single plasmids with high molecular weight. To determine the plasmid harbouring the catabolic genes involved in crude oil degradation, electrophoretic profiles of plasmids isolated from the cured strains were compared with those of the non-cured one. The findings showed that the introduction of the transmissible catabolic plasmid into the indigenous bacteria strains in the oil sludge increase their catabolic ability. Result shown in table 2 with $96 \%$ of oil degradation (Table 2). The transconjugants showed multiplicative effect on the bioremediation process by reducing the biokinetic parameters in ten days while twenty days in immobilised cells.

There a lot of investigations on the effect of inoculation and subsequent transfer of catabolic genes on in situ biodegradation in soils and bioreactors as demonstrated in the present study, such as: Di Giovanni et al. ${ }^{38}$ demonstrated transfer of the IncP-1L plasmid pJP4 from Ralstonia eutropha JMP134 to indigenous

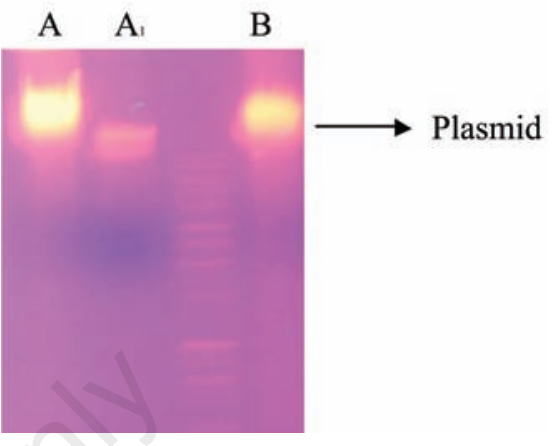

Figure 1. Electrophoretic separation profiles of plasmids from cured and non-cured strains. Lane A: Corynebacterium sp; Lane A1: cured Corynebacterium sp; Lane B: Burkholderia cepacia.

Table 1. Physicochemical characterization of raw and treated wastewater of Kaduna Refining \& Petrochemical Company (KRPC), Kaduna, Nigeria, compared with Federal Environmental Protection Agency (FEPA, Abuja, Nigeria)-Limit.

\begin{tabular}{lcccccc}
\hline Parameters & Raw waste water $(\mathrm{mg} / \mathrm{L})$ & 5 days & $\mathbf{1 0}$ days & $\mathbf{1 5}$ days & 20 days & FEPA-himit \\
pH & $8.00 \pm 0.25$ & $7.55 \pm 0.62$ & $7.23 \pm 0.46$ & $6.72 \pm 0.45$ & $6.55 \pm 0.61$ & - \\
$\mathrm{BOD}_{5}(\mathrm{mg} / \mathrm{L})$ & $236 \pm 0.40$ & $176 \pm 0.36$ & $148 \pm 0.32$ & $96 \pm 1.39$ & $14 \pm 0.23$ & 10 \\
\hline $\mathrm{COD}(\mathrm{mg} / \mathrm{L})$ & $875 \pm 3.92$ & $211 \pm 1.78$ & $169 \pm 1.62$ & $111 \pm 4.33$ & $25.46 \pm 0.46$ & 100 \\
TDS $(\mathrm{mg} / \mathrm{L})$ & $446.4 \pm 5.25$ & $384 \pm 2.32$ & $295 \pm 1.43$ & $201 \pm 2.22$ & $187 \pm 1.58$ & 2000 \\
\hline Phenol $(\mathrm{mg} / \mathrm{L})$ & $68.13 \pm 0.36$ & $42.16 \pm 0.92$ & $21.71 \pm 0.43$ & $10.81 \pm 1.12$ & $0.32 \pm 0.03$ & 10 \\
TPH $(\mathrm{mg} / \mathrm{L})$ & $4.12 \pm 0.56$ & $2.20 \pm 0.36$ & $2.01 \pm 0.082$ & $1.67 \pm 0.32$ & $0.88 \pm 0.12$ & 10 \\
\hline Oil and grease $(\mathrm{mg} / \mathrm{L})$ & $43.20 \pm 2.67$ & $7.3 \pm 0.52$ & $6.12 \pm 0.43$ & $4.63 \pm 0.65$ & $2.53 \pm 0.94$ & 10 \\
Nitrate & $1.87 \pm 0.042$ & $1.71 \pm 0.63$ & $1.68 \pm 0.08$ & $1.60 \pm 0.10$ & $0.62 \pm 0.011$ & 0.05 \\
\hline Sulphate & $32.18 \pm 0.61$ & $24.61 \pm 0.52$ & $19.62 \pm 0.94$ & $14.21 \pm 0.51$ & $8.13 \pm 0.52$ & 2.02 \\
Lead $\left(\mathrm{Pb}^{2+}\right)$ & $0.04 \pm 0.73$ & $0.021 \pm 0.002$ & $0.01 \pm 0.10$ & - & - & 0.05 \\
\hline Iron $\left(\mathrm{Fe}^{2+}\right)$ & $4.30 \pm 0.042$ & $2.28 \pm 0.32$ & $1.243 \pm 0.43$ & $1.003 \pm 0.01$ & $0.181 \pm 0.52$ & - \\
\hline
\end{tabular}

FEPA-Limit, Federal Environmental Protection Agency; BOD5, biochemical oxygen demand; TDS, total dissolved solids; TPS, total petroleum hydrocarbon; COD, chemical oxygen demand. Each value is a mean of 3 replicates \pm standard error.

Table 2. Bioremediation of refinery wastewater using transconjugant.

\begin{tabular}{lccccc} 
Days & Oil and greace $(\mathrm{mg} / \mathrm{L})$ & Phenol $(\mathrm{mg} / \mathrm{L})$ & COD $(\mathrm{mg} / \mathrm{L})$ & \% of oil degraded & Sulphides \\
Raw & $43.20 \pm 3.25$ & $68.13 \pm 3.21$ & $875 \pm 3.67$ & - & $26 \pm 2.43$ \\
2nd & $31.1 \pm 1.21$ & $28.4 \pm 1.23$ & $512 \pm 4.21$ & $14 \pm 2.12$ & $20 \pm 2.12$ \\
\hline 4th & $22.5 \pm 2.76$ & $18.2 \pm 3.23$ & $320 \pm 5.79$ & $46 \pm 2.73$ & $14 \pm 0.23$ \\
6th & $16.11 \pm 1.62$ & $10.8 \pm 2.89$ & $172 \pm 5.39$ & $63 \pm 4.90$ & $11 \pm 2.71$ \\
8th & $8.41 \pm 0.45$ & $4.31 \pm 0.52$ & $96 \pm 4.31$ & $78 \pm 3.80$ & $7.0 \pm 2.09$ \\
10th & $4.27 \pm 0.31$ & $1.06 \pm 0.82$ & $68 \pm 4.54$ & $96 \pm 4.67$ & $4.2 \pm 2.32$ \\
\hline
\end{tabular}

$\mathrm{COD}$, chemical oxygen demand. Each value is a mean of 3 replicates \pm standard error 
soil bacteria when high concentrations of 2,4D were added to the soil.

Top and colleagues ${ }^{39,6}$ studied the effect of conjugative transfer of a few different 2,4-D degradative plasmids on 2,4-D degradation in soil; while Mancini et al. ${ }^{40}$ examined plasmid transfer in an activated sludge unit and found the highest numbers of transconjugants on the bottom of the primary clarifier and in the return-activated sludge from the secondary clarifier, where cell densities are the highest.

Diya'uddeen $e t$ al. ${ }^{30}$ reported that the minimum amount of dissolved oxygen necessary for normal life in an aquatic environment is about $2 \mathrm{mg} / \mathrm{L}{ }^{41}$ and the discharge of high organic matter containing waste waters into water bodies results in the excess consumption of oxygen by the bacteria. This is oxidation of the effluent, thus depleting oxygen from the water faster than it dissolves back into the water from the air. ${ }^{41}$ In addition, oxygen availability is important because the end products of chemical and biochemical reactions in anaerobic systems often produce aesthetically displeasing colours, tastes and odours in water. ${ }^{8}$

Phenol is one of the major pollutants found in refinery effluents. It was found in large concentrations in both the raw wastewater. The major sources of phenol in the petroleum refinery wastewater are the thermal and catalytic cracking processes. The observed value for phenol in raw wastewater was $68.13 \mathrm{mg} / \mathrm{L}$ while both cells were able to reduce it significantly to $(0.32$ and $1.06 \mathrm{mg} / \mathrm{L})$ in both cells. Its content in the treated sample was significantly higher than in transconjugant treated cells $0.5 \mathrm{mg} / \mathrm{L}^{19}$ or $0.1 \mathrm{mg} / \mathrm{L}^{18}$ recommended for refinery effluents.

Phenols are very toxic to fish and other aquatic organisms and has the unique property of tainting fish if present in water at concentration between 0.1 to $1 \mathrm{mg} / \mathrm{L}^{42,43}$ The toxic concentration for fishes may range from $<0.1$ to $>100 \mathrm{mg} / \mathrm{L}$, depending on the chemical nature of the phenol, the fish species and the developmental stage, with embryo-larval stage being many times more susceptible than adults. $^{44}$

Oil and grease and total petroleum hydrocarbon were found to be $(43.20 \pm 2.67)$ to $(2.53 \pm 0.94) \mathrm{mg} / \mathrm{L}$ and $(4.12 \pm 0.56)$ to $(0.88 \pm 0.12) \mathrm{mg} / \mathrm{L}$ in both raw wastewater and treated wastewater respectively after 20 days. Petroleum hydrocarbons have been observed to be toxic to aquatic life. Pollino and Holdway ${ }^{45}$ observed that a water accommodated fraction of crude oil or dispersed crude oil water accommodated fraction increased the activity of gill citrate synthase at a concentration of $14.5 \mathrm{mg} / \mathrm{L}$. Lipophilic hydrocarbons have been observed to accumulate in the membrane lipid bilayers of microorganisms and interfere with their structural and functional proper- ties. ${ }^{46}$ Grant and Briggs ${ }^{47}$ concluded that when oil containing hydrocarbons are discharged into water body can cause depletion of dissolved oxygen due to transformation of organic components into inorganic compounds, loss of that is important in food chain and eutrophication also has short term toxicity in fishes which includes: lymphocytosis, epidermal hyperplasia, hemorrhagic septicaemia., ${ }^{2,30,48}$ At the end of 20 days treatment the isolates were able to reduce the physicochemical parameters of refinery waste water, therefore, mixed culture used in this research work confirmed microbial consortia as better degraders as reported by several authors, ${ }^{49-53}$ therefore, this microbial blend can be adopted in refinery for the treatment of their wastewater before being discharge into waterways.

\section{Conclusions}

The result of the present findings revealed that refinery sludge harbour hydrocarbon degraders and that such organism can be immobilised for reusable purposes and that they carry transmissible catabolic plasmid that can be acquired by other autochthonous bacteria with weak catabolic potentials. This can be used for bioremediation protocol in refinery wastewater treatment.

\section{References}

1. Suleimanov AY. Conditions of waste fluid accumulation at petrochemical and processing enterprise prevention of their harm to water bodies. Meditsina Truda Promyswe Nnaia Ekologila 1995;12:31-6.

2. Uzoekwe SA, Oghosanine FA. The effect of refinery and petrochemical effluent on water quality of Ubeji Creek Warri, Southern Nigeria. Ethiopian J Environ Stud Manag 2011;4:107-16.

3. Coelho A, Castro AV, Dezotti M, Sant'Anna Jr. GL. Treatment of petroleum refinery sourwater by advanced oxidation processes. J Hazard Mater 2006;137:178-84.

4. Doggett T, Rascoe A. Global energy demand seen up 44 percent by 2030 . Washington, DC: REUTERS; 2009. Available from: http:/www.reuters.com/article/2009/05/27/u s-eia-global-demand-idUSN27195286200 90527 Accessed: 17.09.2009.

5. Top EM, Moenne-Loccoz Y, Pembroke T, Thomas CM. Phenotypic traits conferred by plasmids. In: Thomas CM, ed. The horizontal gene pool bacterial plasmids and gene spread. Newark, NJ: Harwood Academic Publishers; 2000. pp 249-85.

6. Top EM, Maila MP, Clerinx M, Goris J, De
Vos P, Verstraete W. Methane oxidation as a method to evaluate the removal of 2,4dichlorophenoxyacetic acid (2,4-D) from soil by plasmid mediated bioaugmentation. FEMS Microbiol 1999;28:203-13.

7. Saien J, Nejati H. Enhanced photocatalytic degradation of pollutants in petroleum refinery wastewater under mild conditions. J Hazard Mater 2007;148:491-5.

8. Leahy JG, Colwell RR. Microbial degradation of hydrocarbons in the environment. Microbiol Rev 1990;45:305-15.

9. Rosenberg E, Ron EZ. Bioremediation oi petroleum contamination. In: Crawford RL, Crawford DL, eds. Bioremediation: principles and applications. Cambridge: Cambridge University Press; 1996.

10. Balba MT, Al-Awadhi R, Al-Daher R. Bioremediation of oil contaminated soil: microbiological methods for feasibility and field evaluation. J Microbiol Methods 1998;32:155-64.

11. Bouchez-Naitali M, Rakatozafy H, Marchals R, Leveau JV, Van Beilendecasteele, JP. Diversity of bacterial strains degrading hexadecane in relation to the mode of substrate uptake. J Appl Microbiol 1999;86:42128.

12. Margesin R, Labbé D, Schinner F, Greer CW, Whyte LG. Characterization of hydrocarbon-degradative microbial populations in contaminated and pristine alpine soils. Appl Environ Microl 2003;69:3085-92.

13. Nweke CO, Okpokwasili GC. Effects of bioremediation treatments on the bacterial populations of soil at different depths. Nig J Microbiol 2004;18:363-72.

14. Kaplan CW, Kitts CL. Bacterial succession in a petroleum land treatment unit. Appl Environ Microbiol 2004;70:1777-86.

15. Quatrini P, Scaglione G, De Pasquale C, Reila S, Puglia AM. Isolation of Gram-positive n-alkane degraders from a hydrocarbon contaminated Mediterranean shoreline. J Appl Microbiol 2008;104:251-9.

16. Top EM, Springael D, Boon N. Erratum to catabolic mobile genetic elements and their potential use in bioaugmentation of polluted soils and waters. FEMS Microbiol Ecol 2002;42:199-08.

17. Sanni Gbemisola 0, Ajisebutu 0 . Biodegradation of Escravos light crude oil by some species of soil bacteria. Sci Focus 2003;4:85-7.

18. Department of Petroleum Resources (DPR). Environmental Guidelines and standards for the petroleum industry in Nigeria, production and terminal operations. Abuja: Department of Petroleum Resources, Ministry of Petroleum Resources; 1991.

19. Federal Enviromental Protection Agency (FEPA). 1995 corporate profile, Garki, FCT, Abuja, Nigeria 1991 REFERENCE NOT 
CLEAR - IS IT A BOOK? OR A MINISTERIAL DECREE? OTHER? please provide a link to find it

20. American Public Health Association (APHA). Standard methods for examination of water/wastewater. Washington, DC; APHA-AWWA-WPCF; 1995. no. 20036.

21. American Society for Testing and Materials (ASTM). Annual book of ASTM standards. Philadelphia: ASTM; 1979. p 1527.

22. Joel OF, Amajuoyi CA. Physicochemical characteristics and microbial quality of an oil polluted site in Gokana, River State. J Appl Sci Environ Manage 2009;13:99-103.

23. Ademoroti CMA. Chapter 2: Environment microbiology and medical science on bioremediation. In: Ademoroti CMA, ed. Standard methods for water and effluent analysis.1st ed. Ibadan: Foludex press, Ltd.; 1996. pp 20-50.

24. Adinarayana K, Jyothi B, Ellaiah P. Production of alkaline protease with immobilized cells of bacillus subtilis. AAPS Pharm Sci Tech 2005;6:391-7.

25. Margesin R, Schinner F, eds. Manual for soil analysis - monitoring andassessing soil bioremediation. Berlin-Heidelberg: Springer; 2005.

26. Bathe S, Hausner M. TITLE OF THE CHAPTER??? In: Cummings SP, ed. Bioremediation, methods in molecular biology 599???. CITY???: Humma press; 2010. pp 185-200.

27. Ojo A0, Oso BA. Isolation of plasmid DNA from synthetic detergent degraders in waste water from a tropical environment. Afr J Microbiol Res 2009; 3:123-7.

28. Ahrne S, Molun G, Staahl S. plasmids in Lactobacillus strains isolated from meat and meat products system. Appl Microbial 1989;11:320-5.

29. Bhalakia N. Isolation and plasmid analysis of vancomycin resistant Staphylococcus aureus. J Young Invest 2006;15:15-24.

30. Diya'uddeen, Basheer H, Wan Mohd A, Wan D, Abdul Aziz AR. Treatment technologies for petroleum refinery effluents: a review. Proc Safe Environ Protect 2011;89:95-105.

31. Igbinosa EO, Oko AI. Impact of discharge wastewater effluents on the physiscochemical qualities of a receiving watershed in a typical rural community. Int $\mathrm{J}$ Environ Sci Tech 2009;6:175-82.

32. Thavan R, Jayalakshmi S, Radha Krisnan $\mathrm{R}$, Balasubramanian T. Plasmid incidence infour species of hydrocarbonate bacteria isolated from oil polluted marine environment. Biotechnology 2007;6:349-52.

33. Mirdamadian SH, Entiazi G, Golabi MH, Ghanavati H. Biodegradation of petroleum and Aromatic hydrocarbons by bacteria isolated from petroleum contaminated soil. J Pet Environ Biotechnol 2010;1:102.

34. Toledo FL, Calvo C, Rodelas B, GonzálezLópez J. Selection and identification of bacteria isolated from waste crude oil with polycyclic aromatic hydrocarbons removal capacities. System Appl Microbiol 2006;29:244-52.

35. Whyte LG, Bourbonnière L, Greer CW. Biodegradation of petroleum hydrocarbons by psychrotrophic Pseudomonas Pseudomonas strains possessing both alkane (alkalk) and naphthalene (nahnah) catabolic pathways. Appl Environ Microbiol 1997;63:3719-23.

36. Kumar R, Singla R, Kumar G. Plasmid associated anthracene degradation by Pseudomonas sp isolated from fitting stating site. Nature Sci 2010;8:89-94.

37. Coral G, Karagoz S. Isolation and characterization of phenan threne - degrading bacteria from a petroleum refinery soil. Annals Microbiol 2005;55:255-59.

38. DiGiovanni GD, Neilson JW, Pepper IL, Sinclair NA. Gene transfer of Alcaligenes eutrophus JMP134 plasmid pJP4 to indigenous soil recipients. Appl Environ Microbiol 1996;62:2521-6.

39. Top EM, Van Daele P, De Saeyer N, Forney LJ. Enhancement of 2,4-dichlorophenoxyacetic acid (2,4-D) degradation in soil by dissemination of catabolic plasmids. Antonie Van Leeuwenhoek 1998;73:87-94.

40. Mancini P, Fertels S, Nave D, Gealt MA. Mobilization of plasmid pHSV106 from Escherichia coli HB101 in a laboratoryscale waste treatment facility. Appl Environ Microbiol 1987;53:665-71.

41. Attiogbe FK, Glover-Amengor M, Nyadziehe KT. Correlating biochemical and chemical oxygen demand of effluentsa case study of selected industries in Kumasi, bacteria from coastal water. Biotechnol Bio Eng 2007;14:297-308.

42. De-Bruin DB. A bacterial bioassay for assessment of waste-water toxicity - In: Kenneth J, ed. Mechanism of toxicity for various compounds. Wat-Res. G. Britain; 1976. pp 383-90.

43. Staples CA, Dorn PB, Klecka GM, O'Block ST, Harris LR. A review of the environmental fate, effects and exposures of bisphenol A. Chemosphere 1998;36:2149-73.

44. DeGraeve GM, Geiger DL, Meyer JS, Bergman HL. Acute and embryolarval toxicity of phenolic compounds to aquatic biota. Arch Environ Contam Toxicol 1980;9:557-68.

45. Pollino CA, Holdway DA. Hydrocarboninduced changes to metabolic and detoxification enzymes of the Australinan crimson-spotted rainbow fish (Melanotaeni fluviatilis). Environ Toxicol 2003;18:21-8.

46. Sikkema JA, deBont AM, Poolman B. Mechanisms of membrane toxicity of hydrocarbons. Microb Rev 1995;59:201-22.

47. Grant A, Briggs AD. Toxicity of sediments

from around a North Sea oil platform: are

metals or hydrocarbons responsible for

ecological impacts? Marine Environ Res

2002;53:95-116.

48. Beeby A. Measuring the effect of pollution.

In: Beeby A, ed. Applying ecology. London-

New York: Chapman and Hall; 1993.

PAGES???????

49. Obire 0 . Studies on the biodegradation potential of some microorganisms isolated from water systems of two petroleum-producing areas in Nigeria. Nig $\mathrm{J}$ Bot $1988 ; 1: 81-90$

50. Amund 00, Nwokaye N. Hydrocarbon degradation potentials of yeast isolates from a polluted lagoon. J Sci Res Dev 1993;1:61-4.

51. Facundo JMR, Vaness HR, Teresa ML. Biodegradation of diesel oil in soil by a microbial consortium. Water Air Pollut 2001;129:313-20.

52. Kulwadee T, Vithaya M, Prayad P, Attawut I.

Isolation and characterisation of crude oil degrading bacteria in Thailand. Int Conf on 'New Horizons in Biotechnology', April 18-21, Trivandruim, India. CITY???? PYBLISHER???; 2001.

53. Ndip RN, Akoachere JF, Akeniji TN, Yongabi FN, Nkwekang G. Lubrication oil degrading bacterial in soils from filling stations and auto mechanic workshops in Buea, Cameroon occurrence and characteristics of isolates. Afr J Biotechnol 2008;11:1700-6. 